\title{
Pan Whicher w przedpowstaniowej Warszawie i radca Estar Van Houten w sklepie Wokulskiego - kryminat historyczny jako opowieść o przeszłości
}

Kryminał historyczny uważany jest za hybrydyczną konwencję gatunkową, zawierającą w sobie zarówno elementy powieści historycznej, jak i kryminalnej. Owo zmieszanie dwóch porządków ma swoje odzwierciedlenie między innymi $\mathrm{w}$ różnym lokowaniu genologicznym: konwencja ta postrzegana jest albo jako subgatunek powieści historycznej, albo kryminalnej. Przeważa jednak pogląd, że jest to odmiana drugiej z nich ${ }^{1}$ i definiuje jako powieść kryminalną, w której fabuła, zbudowana wokół intrygi kryminalnej, osadzona jest w czasie - z perspektywy autora - historycznym². Sytuowanie kryminału historycznego w obrębie powieści historycznej ${ }^{3}$ eksponuje kwestię sposobu prezentacji przeszłości historycznej oraz rolę zdarzeń historycznych w konstrukcji fabuły. Jak zauważa Heather Worthington, mimo sporej liczby tekstów powstających w konwencji kryminału historycznego, teoretyczna świadomość pojawienia się nowego subgatunku

* Dr hab., prof. UŁ; Uniwersytet Łódzki, Wydział Filologiczny, Katedra Teorii Literatury; ul. Pomorska 171/173, 90-236 Łódź; e-mail: agnieszka.izdebska@uni.lodz.pl.

1 Zob. na przykład P. Kaczyński, Kryminat historyczny - próba poetyki, w: Literatura kryminalna. Śledztwo w sprawie gatunków, pod red. A. Gemry, Wydawnictwo EMG, Kraków 2014, s. 191; też: K. Dominas, Antyk w kryminale, kryminat w antyku. Steven Saylor i recepcja literatury antycznej, w: Literatura kryminalna. Na tropie źródet, pod red. A Gemry, Wydawnictwo EMG, Kraków 2015, s. 221; R.W. Winks, Preface, w: The Detective as Historian: History and Art in Historical Crime Fiction, ed. R.B. Browne i L.A. Kreiser, Jr, Bowling Green, 2000, s. ix.

2 Zob. A. Izdebska, Kryminał historyczny, "Zagadnienia Rodzajów Literackich” 2016, t. 59, z. 4 (120), s. 137-143.

3 Zob. na przykład: F.A. Salamone, Maan Meyers: The Saga of Dutchman, w: The Detective as Historian..., s. 160; też: D. Bradshaw Smith, Bruce Alexander: Sir Henry Fielding and Blind Justice, w: The Detective as Historian..., s. 175. 
rozwinęła się u schyłku wieku dwudziestego ${ }^{4}$ i zaowocowała powstaniem wielu literaturoznawczych analiz ${ }^{5}$. Niektóre $\mathrm{z}$ nich zawierają próby opisania przyczyn ogromnej popularności tej formy kryminału, objawiającej się dużą liczbą tekstów, które da się zaklasyfikować jako realizujące założenia tego subgatunku. Źródło tej popularności upatrywano między innymi w czytelniczej potrzebie śledzenia procesu rozwiązywania zagadki kryminalnej w realiach odległych od współczesności, przez to mniej angażujących emocjonalnie niż - zawsze złożona i skomplikowana - rzeczywistość, w której czytelnicy żyją ${ }^{6}$. Zatem odbiorcy tej odmiany kryminału bez wątpienia nie podzielają gustu Ruperta, jednego z członków grupy Tropiciele Zbrodni - wielbicieli powieści kryminalnych spotykających się w malowniczym Bath, miejscu akcji powieści Petera Loveseya Detektyw Diamond i tajemnica zamkniętego pokoju. Ów Rupert wychwala autorów znacznie odchodzących od modelu powieści detektywistycznej, wypracowanego między innymi przez Agathę Christie: „Żadnych dworków na wsi, tylko getta, gdzie dzieciaki noszą spluwy i zabijają za crack [...]. Nory zaśmiecone używanymi strzykawkami, z zawszawionymi materacami, karaluchy zjadające zeschłe wymiociny"7. Nadto - poza unikaniem dotkliwego kontaktu z najmroczniejszymi aspektami współczesnych zbrodni - kryminał historyczny oferuje ożywczy powrót do opowieści z początków gatunku: oto detektyw rozwiązuje zagadkę kryminalną z dala od skomplikowanych procedur i nowoczesnych laboratoriów ${ }^{8}$.

Analiza rozmaitych tekstowych realizacji tej formy gatunkowej wskazuje, że dla autorów ją wykorzystujących najbardziej kłopotliwym elementem konwencji jest prezentacja przeszłości i splecenie zdarzeń historycznych z wątkiem kryminalnym. W obrębie kryminału historycznego mamy do czynienia zarówno z tekstami eksponującymi wydarzenia historyczne, jak i traktującymi je jako mniej lub bardziej istotne tło pierwszoplanowej intrygi kryminalnej. Nadto melanż atrakcyjnie pokazanej historii i ekscytującej zagadki kryminalnej owocuje wyraźną - wobec zasady prawdopodobieństwa - nadwyżką spisków politycznych, w których ujaw-

4 „Much crime fiction may be considered to write the recent history of present, but it is only in the later twentieth century that the increasing and deliberate use of the often distant past as setting for crime narratives has led to the acknowledgment of 'historical crime fiction' as a recognised sub-genre" (H. Worthington, Key Concepts in Crime Fiction, Palgrave MacMillan, London 2011, s. 130).

5 Zob. The Detective as Historian: History and Art in Historical Crime Fiction, ed. R.B. Browne i L.A. Kreiser, Jr, Bowling Green, 2000; The Detective as Historian: History and Art in Historical Crime Fiction Volume II, ed. R.B. Browne i L.A. Kreiser, Jr, Newcastle 2007; zob. też: J. Scaggs, Historical Crime Fiction, w: Scaggs, Crime Fiction, Routledge, London \& New York, 2005.

6 Zob. H. Worthington, dz. cyt., s. 130.

7 P. Lovesey, Detektyw Diamond i zagadka zamkniętego pokoju, przeł. R. Januszewski, Wydawnictwo Amber, Warszawa 2009, s. 27.

8 Zob. R.W. Winks, dz. cyt., s. xi. 
nianie zaangażowani są protagoniści. Co więcej, niepokojąco często są oni świadkami najistotniejszych wydarzeń danej epoki. Daje to taki efekt, jakby w każdej powieści kryminalnej, której akcja ulokowana jest w Stanach Zjednoczonych w XX wieku, główny bohater natykał się na ślady odsyłające go do okoliczności zabójstwa prezydenta Kennedy'ego czy do afery Watergate ${ }^{10}$.

Ślad złożoności relacji między intrygą kryminalną a faktami historycznymi $\mathrm{w}$ tekstach realizujących założenia omawianego tu subgatunku widać również $\mathrm{w}$ autorskich wypowiedziach paratekstowych, które tak często występują w kryminałach historycznych, że ich istnienie uznano za element konwencji"'. Większość z nich poświęcona jest właśnie owemu nieprostemu mariażowi. Już Agatha Christie zatem poprzedziła powieść Zakończeniem jest śmierć (Death Comes at the End, 1944, pol. 1945) ${ }^{12}$ wstępem, w którym określiła czas i miejsce akcji, wykładając czytelnikom zawiłości kalendarza rolniczego w starożytnym Egipcie. Odautorskie uwagi pojawiające się w kolejnych posłowiach lub wstępach do kryminałów historycznych odnoszą się np. do możliwych anachronizmów w konstrukcji głównej postaci - Lindsey Davis, Srebrne świnki (The Silver Pigs 1989, pol. 2009), czy Ellis Peters, Niezwykly benedyktyn (A Rare Benedictine 1979, pol. 2014), ale najczęściej stanowią komentarze na temat relacji między zdarzeniami powieściowymi a faktami historycznymi. W niektórych przypadkach mamy nawet do czynienia z krytyczną analizą źródeł - np. Stevena Saylora Rzymska krew (Roman Blood 1991, pol. 2001) czy Zagadka Katyliny (Catilina's Riddle 1993, pol. 2002). Zatem we wszystkich metatekstowych uwagach odautorskich, które pojawiają się w powieściach tego gatunku, nie tylko eksponowany jest jego związek z konwencją powieści historycznej, ale i powraca się do dylematów, które w obrębie dyskusji dotyczącej powieści historycznej właśnie wydają się nieaktualne: np. kwestia relacji fikcja - źródła, fikcja - fakty historyczne, czy też nieuchronny anachronizm wpisany w konwencję - pochodna nieusuwalnej obcości przeszłości.

W polskiej praktyce krytycznej stosuje się rozróżnienie na kryminał retro i kryminał historyczny. Za wyznacznik tego ostatniego Paweł Kaczyński uznaje

9 Na przykład główna bohaterka powieści Ariany Franklin Labirynt śmierci (The Death Maze, 2008), medyczka Adela Aquilar, odkrywając rzeczywistego sprawcę otrucia kochanki Henryka II, uwalnia jego żonę, Eleonorę Akwitańską od podejrzeń i zapobiega ponownej, krwawej wojnie domowej w XII-wiecznej Anglii. Natomiast Gordianus, detektyw, o którego przygodach opowiada cykI Roma Sub Rosa Stevena Saylora jest blisko spisku Katyliny, zapobiega zamachowi na życie Cezara, zaś w czasie podróży do Aleksandrii jest świadkiem zabójstwa Pompejusza, a potem przybycia Kleopatry (jak wiadomo, ukrytej w dywanie) do komnaty wodza Rzymian. D.N. Eldridge, T.M. Westervelt, E.L. Meek, Michael Clynes: The Recollections of Shallot, w: The Detective as Historian: History and Art in Historical Crime Fiction, ed. R.B. Browne and L.A. Kreiser Jr, Bowling Green State University Popular Press, Bowling Green, 2000, s. 156.

11 P. Kaczyński, dz. cyt., s. 199-200.

12 Powieść ta - niesłusznie - uznawana jest za pierwszy kryminał historyczny. 
osadzenie akcji w czasach sprzed narodzin nowoczesnych instytucji policyjnych i powstania agencji detektywistycznych ${ }^{13}$. Jednak obie te konwencje bez wątpienia łączy jedno: konieczność ukonstytuowania świata przedstawionego, w którym czytelnik poruszałby się na tyle swobodnie, by śledzić intrygę kryminalną, mimo iż jest to świat mu obcy. Owa obcość fundowana jest przede wszystkim oddaleniem $\mathrm{w}$ czasie $^{14}$ - kwestia, jak znacznym, jest tu marginalna: Warszawa w roku 1862 i Rzym za czasów panowania Wespazjana są miejscami dla współczesnych niemal równie egzotycznymi, a opowieści o toczących się wówczas śledztwach wymagają takiego wprowadzenia w ów obcy świat, by czytelnik śledził perypetie kryminalne z emocjonalnym zaangażowaniem ${ }^{15}$.

Wiek XIX w kulturze popularnej wieków następnych, jako nie tylko czas zdarzeń, ale i zarazem obiekt przedstawienia, pojawia się bardzo często ${ }^{16}$. W euroatlantyckim kręgu kulturowym neowiktorianizm ${ }^{17}$ na przykład jest zjawiskiem żywo obecnym i mającym różne konwencjonalne wcielenia - m.in. steampunk $u^{18}$. W obszarze anglojęzycznym owa popularność epoki rządów królowej Wiktorii i jej następcy bierze się z dwuznacznych emocji, związanych z nostalgią za prostotą moralną niegdysiejszego imperium, i zarazem $z$ impulsu do dokonywania rewizji owego obrazu. Zdaniem Worthington, osadzanie fabuły kryminału historycznego w epoce wiktoriańskiej i czasach edwardiańskich wynika właśnie z tego, że stały się one doskonale znane odbiorcom za sprawą rozlicznych opowieści filmowych i telewizyjnych, jak również postrzegane są jako przeszłość relatywnie bliska współczesności ${ }^{19}$.

Jednak w polskiej historii i literaturze wiek XIX to okres szczególnie obciążony emocjonalnie. Życie pod zaborami, brak własnego państwa, kolejne, krwawo

13 P. Kaczyński, dz. cyt., s. 191-192.

14 Zob. D. Lowenthal, Przeszłość to obcy kraj, przeł. I. Grudzińska-Gross i M. Tański, „Res Publica” 1991, nr 3, s. 6-22.

15 Zob. P. Kaczyński, dz. cyt., s. 193-197; też H. Worthington, dz. cyt., s. 134.

16 W polskim literaturoznawstwie pisali na ten temat m.in. E. Paczoska, Wiek XIX - reaktywacja, w: tejże, Prawdziwy koniec XIX wieku. Śladami nowoczesności, Państwowy Instytut Wydawniczy, Warszawa 2010, s. 244-262 oraz D. Piechota, Reaktywacje dziewiętnastowieczności w najnowszej literaturze popularnej, „Tematy i Konteksty” 2015, nr 5 (10), s. 175-184. Oba teksty dotyczą jednak ostatecznie zagadnień węższych, niż zapowiedziane w ich tytułach.

17 W kwestii komplikacji terminologicznych związanych z rozmaitością nawiązań do epoki wiktoriańskiej zob. M. Sulmicki, A Plenitude of Prefixes: Delineating the Boundaries of Neo-, Retro-, Faux-, Post-Victorian Literature, „Zagadnienia Rodzajów Literackich” 2015, t. 18, z. 1 (115), s. 9-26.

18 Steampunk uważany jest za podgatunek literatury science fiction, wywodzący się z cyberpunku. Opowieści powstające w tej konwencji odnoszą się do alternatywnej wersji rzeczywistości, najczęściej dziewiętnastowiecznej właśnie, w której cały rozwój cywilizacyjny toczy się w oparciu o technologie oparte na źródłach energii w postaci pary i elektryczności. Zob. N. Lemann, Steampunk, „Zagadnienia Rodzajów Literackich” 2014, t. 17, z. 1 (113), s. 344-349. 
tłumione powstania, próba dokonania skoku modernizacyjnego - to tylko kilka elementów składających się na jego obraz. Nadto doświadczenia te znalazły swoją reprezentację $\mathrm{w}$ bardzo intensywnie obecnym i w latach późniejszych paradygmacie romantycznym ${ }^{20}$, który odcisnął niezwykle silne piętno przede wszystkim na języku, w jakim się ów czas opisuje. Ślad tej dykcji, a zarazem melanż kompensacyjnego i nostalgicznego nastawienia do polskich dziewiętnastowiecznych doświadczeń historycznych można również znaleźć $\mathrm{w}$ alternatywnej wersji przeszłości pojawiającej się w polskim steampunku²1.

Przedmiotem analizy w niniejszym artykule chciałam uczynić dwie powieści, których akcja toczy się w wieku XIX: Pan Whicher w Warszawie autorstwa dwojga pisarzy - Agnieszki Chodkowskiej-Gyurics i Tomasza Bochińskiego oraz Carska roszadę Melchiora Medarda. Pierwszy z tych tekstów jednoznacznie wpisuje się $\mathrm{w}$ formułę gatunkową kryminału historycznego, przynależność genologiczna drugiego z nich będzie tu rozważana jako nieoczywista.

Akcja powieści dwojga pisarzy toczy się w Warszawie od końca sierpnia do początku listopada 1862 roku. Tytułowy angielski detektyw to słynny Jonathan "Jack” Whicher, członek niewielkiej grupy śledczych powołanej w Scotland Yardzie do prowadzenia dochodzeń $\mathrm{w}$ sprawach kryminalnych po cywilnemu ${ }^{22}$. Śledztwo, podczas którego współpracuje z rosyjskimi kolegami dotyczy zarówno tajemniczego zniknięcia księżnej Dołgorukiej, a przedtem jej córki Darii, jak i morderstw młodych mężczyzn, których zmasakrowane ciała, trudne do identyfikacji, porzucane są na ulicach. W rezultacie okaże się, że obie kobiety padły ofiarą morderstwa, jednak sprawy nie są powiązane: ich zabójstwa to wynik intryg spadkowo-rodzinnych, zaś mordy na młodych Polakach stanowią część rozgrywki policji politycznej, chcącej skompromitować i skłócić prących do powstania spiskowców.

Autorzy Pana Whichera $w$ Warszawie i w tym względzie podporządkowują powieść regułom gatunku, że zamieszczają w niej posłowie o wyraźnym wymiarze

20 Nie sposób w tym tekście, nawet zwięźle, zrelacjonować dyskusji wobec ewentualnego wygaśnięcia w kulturze polskiej owego paradygmatu. W tej kwestii odsyłam do wstępu książki Ewy Paczoskiej Prawdziwy koniec XIX wieku..., s. 8-9.

21 Zob. N. Lemann, Polski steampunk - zaadaptować historię, adaptujac konwencję, „Postscriptum Polonistyczne" 2015, nr 5: Adaptacje II. Transfery kulturowe, s. 138. Na przykład w powieści Konrada T. Lewandowskiego Orzeł bielszy niż gołębica powstańcy w 1863 wygrywają z Rosją dzięki użyciu czołgów skonstruowanych przez Ignacego Łukasiewicza.

22 Postać detektywa, a przede wszystkim jego najsłynniejsze śledztwo, morderstwo kilkuletniego syna państwa Kentów, zostało opisane przez Kate Summerscale, Podejrzenia pana Whichera: morderstwo w domu na Road Hill (wyd. pol. Wydawnictwo W.A.B., Warszawa 2010, przeł. M. Jaszczurowska). Na ten fabularyzowany dokument powołują się zresztą autorzy kryminału, a konstrukcja postaci angielskiego detektywa jest wyraźnie inspirowana tekstem Summerscale. W 2014 roku powstał też brytyjski serial telewizyjny Podejrzenia pana Whichera w reżyserii Jamesa Hawesa. 
- co oczywiste, przy tego typu paratekście - metatekstowym. Zaczyna się ono od zdania: „Książka, którą trzymasz w ręku, nie aspiruje do miana powieści stricte historycznej. To raczej kryminał $\mathrm{z}$ historią $\mathrm{w}$ tle ${ }^{23}$. Jednakże tło [...] potrafi być opowieścią samą w sobie. Zrobiliśmy więc, co w naszej mocy, by ludzie, obyczaje i miejsca, które opisujemy, odpowiadały ówczesnym czasom" (PWW, 487). Po takiej deklaracji następuje prezentacja postaci Whichera i krótkie wzmianki o postaciach historycznych pojawiających się w powieści. Piszący wyjaśniają żart związany z nazwiskiem rosyjskiego śledczego, z którym angielski detektyw w Warszawie współpracuje. Brzmi ono Mikołaj Czernyszewski - i choć rosyjski policjant jest postacią całkowicie fikcyjną, nosi tu nazwisko znanego dziewiętnastowiecznego filozofa, socjalisty utopijnego. Autorzy tłumaczą się też z dokonywania korekty historycznego tła, o którego wycyzelowanie tak dbają - walor zapachowy ówczesnej Warszawy został celowo pominięty, by nie epatować czytelników odorami miasta pozbawionego systemu kanalizacyjnego ${ }^{24}$. Piszący dają też zwięzłą interpretację sporów wśród polskich działaczy politycznych tego czasu i diagnozują przyczyny upadku powstania styczniowego ${ }^{25}$. Otrzymujemy również krótką informację na temat technik policyjnych stosowanych w 1862: sposobów identyfikacji podejrzanych i metod badania krwi. Zatem piszący w posłowiu zdecydowali się uzupełnić wiedzę odbiorcy o fakty - w ich mniemaniu - niezbędne dla czytelnika modelowego $^{26}$, aby możliwe było rozróżnienie, które zdarzenia powieściowe odsyłają do faktów historycznych w przeciwieństwie do tych, których źródłem jest jedynie inwencja pisarska ${ }^{27}$.

23 Wszystkie cytaty w tekście za wydaniem: A. Chodkowska-Gyurics, T. Bochiński, Pan Whicher w Warszawie, Instytut Wydawniczy Erica, Warszawa 2012, oznaczone są skrótem PWW. Swoją drogą ta predylekcja do wyjaśniania czytelnikom, co właśnie przeczytali, u autorów jednego z najpopularniejszych obecnie subgatunków powieści popularnej jest wielce zastanawiająca. Świadczy to o tym, zapewne, że zdaniem wielu autorów, czytelnicza świadomość genologiczna w przypadku tego subgatunku jest dość nieokreślona przez fundującą go hybrydyczność.

24 Jak wiadomo, ostatecznie kanalizację Warszawa zawdzięcza energicznym staraniom generała Sokratesa Starynkiewicza, pełniącego obowiązki prezydenta miasta w latach 1875-1892. Zob. M.M. Drozdowski, A. Zahorski, Historia Warszawy, Wydawnictwo Jeden Świat, Warszawa 2004 , S. 194.

25 Piszą: „Brak zgody narodowej, ciągłe spory, a nawet walki frakcyjne kładą się cieniem na powstaniu styczniowym. O cóż tak zajadle się kłócono? O kwestię chłopską głównie" (PWW, 491).

26 Zob. U. Eco, Lector in fabula. Współdziałanie w interpretacji tekstów narracyjnych, przeł. P. Salwa, Państwowy Instytut Wydawniczy, Warszawa 1994, s. 72-96.

27 Zostawiając na boku absurdalność tego rozróżnienia (tj. faktów historycznych i fikcyjnych w obrębie powieści, zatem fikcji literackiej), przytaczam fragment posłowia: „Podczas lektury powieści osadzonej w realiach historycznych Czytelnik często zadaje sobie pytanie, co jest prawdą, a co fikcją literacką? Które osoby żyły naprawdę, a które są tylko tworami wyobraźni autora? Oczywiście, nikogo nie trzeba przekonywać, że wielki książę Konstanty to postać 
Albowiem Pan Whicher w Warszawie to opowieść, w której - poza oczywistym elementem: intrygą kryminalną - pojawia się też spora dawka faktów historycznych i postaci działających w przedpowstaniowej Warszawie, jednym słowem mamy tu do czynienia z próbą odtworzenia $\mathrm{w}$ tej właśnie konwencji gatunkowej atmosfery sprzed wybuchu insurekcji 1863 roku. Obserwujemy zatem gorączkowe rozmowy prowadzone w gronie działaczy o konserwatywnych poglądach zgromadzonych wokół Leopolda Kronenberga - „białych”. Jako postaci powieściowe pojawiają się: sam bankier, Józef Ignacy Kraszewski, Karol Ruprecht, Karol Majewski, Agaton Giller. Z przeciwnego obozu politycznego poznajemy Zygmunta Padlewskiego i Ignacego Chmieleńskiego, jeśli chodzi zaś o urzędników rosyjskich tego czasu, pojawia się przede wszystkim pułkownik żandarmerii Teodor Tuchołko, wsławiony później represjami przewodniczący komisji prowadzącej popowstaniowe śledztwa. Spoza ścisłego grona głównych graczy politycznych tych czasów autorzy umieszczają wśród bohaterów powieściowych na przykład Teofila Wisłockiego, mającego w Szkole Głównej wykłady z medycyny sądowej i profesora anatomii patologicznej w warszawskiej Akademii Medyko-Chirurgicznej.

Czas przedpowstaniowy w Warszawie, jak na wymagania konwencji przystało, pokazany jest w powieści dość widowiskowo i atrakcyjnie. Obserwujemy zatem spory frakcji politycznych dzielących polskich spiskowców - „czerwonych” radykałów i „białych” konserwatystów, i wiemy, że nieuchronnie nadchodzący styczeń 1863 roku unieważni niejako różnice ich poglądów. Ale przede wszystkim intryga Pana Whichera $w$ Warszawie koncentruje się wokół historii bardzo specyficznej formacji działającej w tym czasie - sztyletników. Ta grupa, najsilniej zakonspirowana spośród wszystkich składających się na państwo podziemne, pełniła funkcję policji. Jak pisze Paulina Małochleb: „Początkowo sztyletnicy mieli chronić rząd przed agentami rosyjskimi, szybko jednak otrzymali prawo wykonywania wyroków śmierci, określonych przez ustawodawstwo Rządu Narodowego" ${ }^{28}$. Stosunek do tego aspektu powstania ewoluował w czasie i odzwierciedlał niejednoznaczność opinii polskiego społeczeństwa o działaniach terrorystycznych jako moralnie wątpliwych. Autorka cytowanej już pracy stwierdza:

Zarówno ugodowcy, jaki tradycyjnie myśląca część społeczeństwa stworzyła czarną, mroczną mitologię sztyletników jako ludzi mających zabijanie we krwi. Jeszcze w czasie trwania powstania próbowano się odciąć od radykalnych poglądów zamachowców. Po powstaniu zaś [...] narracje o sztyletnikach stały się dyskursem

historyczna, jednak z resztą dramatis personae Odbiorcy może nie pójść tak łatwo, dlatego postaramy się w tej sprawie pomóc" (PWW, 489).

28 P. Małochleb, Sztyletnicy powstania styczniowego - historiografia i literatura. Rekonesans, „Teksty Drugie" 2008, nr 3, s. 185. 
wstydliwym, pamięć o policji narodowej została stłumiona i wyparta, a nieliczne przywołania miały na celu ich zohydzenie, przedstawienie ich narodowej i ideowej obcości ${ }^{29}$.

W okresie późniejszym opowieść o sztyletnikach układała się wedle porządków nieprzystających do siebie. Z jednej strony, w dwudziestoleciu międzywojennym, wpisywała się w porządek bliski gatunkowo powieści awanturniczej, eksponującej przygodowy aspekt ich działalności. Pokazywano ich zatem jako śmiałków uciekających w przebraniach, po dachach, wodzących za nos ścigających ich Rosjan. W latach sześćdziesiątych i siedemdziesiątych XX wieku przedstawiano ich jako przykład radykalnych postaw robotników i rzemieślników, zaś nieco później pisarze, tacy jak Władysław L. Terlecki czy Stanisław Rembek, podkreślali raczej egzystencjalny, tragiczny wymiar ich wyborów ${ }^{30}$.

Powieść Pan Whicher $w$ Warszawie oczywiście nie przywołuje ambiwalencji i komplikacji owego obrazu sztyletników ukształtowanego i w historiografii, i w literaturze pięknej ostatnich 150 lat, choć można w niej dostrzec pewne echa tej niejednoznaczności. Jednak, głównie ze względów gatunkowych, pokazuje zamachowców raczej w konwencji awanturniczej, niż odwołując się, na przykład, do dylematów Białego z powieści Terleckiego Zwierzęta zostały opłacone. Niemniej, jak się wydaje, $\mathrm{w}$ takiej, popularnej formie, powieść przywraca pamięć o sztyletnikach - to poznawczy wymiar kryminału historycznego. Tym bardziej, że w tekście widać ślady lektur źródłowych autorów - jako postaci powieściowe pojawiają się historyczni sztyletnicy z Emanuelem Szafarczykiem na czele, a ich dialog: „Weźmiesz swoją dziesiątkę i schowasz Anglika i Czernyszewskiego" (PWW, 135), przywołuje specyficzne znaczenie czasownika „schować”, w jakim w tej grupie był używany ${ }^{31}$.

Autorzy Pana Whichera $w$ Warszawie prowadzą jednak dość złożoną grę z oczekiwaniami czytelników, ich wiedzą historyczną i ewentualną znajomością tekstów literackich odnoszących się do tego okresu. Na przykład w jednej ze scen Kronenberg wymienia nazwisko „Grabowski”, zaś w finale powieści mówi: „Czerwoni są w błędzie, trzeba ich powstrzymać, ale prowokowanie ich do pojedynków, gdzie my wystawiamy doborowych strzelców, a oni urzędników albo uczniów...” (PWW, 470). Dla odbiorców znających dzieje powstania styczniowego lub/i czytających powieść Władysława Terleckiego Spisek to oczywista aluzja do śmierci w pojedynku Stefana Bobrowskiego, „czerwonego”, dwudziestotrzyletniego naczelnika Warszawy, faktycznego przywódcy powstania w tym czasie. Zdarzenie to

29 Tamże, s. 188.

30 Tamże, s. 190-191.

31 P. Małochleb pisze: „Poszukujący wzniosłości nawet w zamachu, pełni rewolucyjnej egzaltacji romantycy, ustąpili miejsca nowemu modelowi walki skrytej, którego wykonawcy nazywali zamach «uspokojeniem» lub «schowaniem» winnego" (tamże, s. 189). 
uważa się za mord polityczny - krótkowzroczny Bobrowski zginął z ręki hrabiego Adama Grabowskiego, będącego narzędziem przeciwników politycznych, energicznego, rzutkiego dyktatora o radykalnych poglądach. Jak się wydaje - taka gra z czytelniczą wiedzą co do ciągu dalszych prezentowanych zdarzeń jest typowa dla powieści historycznej ${ }^{32}$.

Nawiasem mówiąc, sam przyszły przywódca powstania pokazany jest $\mathrm{w}$ powieści Chodkowskiej-Gyurics i Bochińskiego w sposób nieco groteskowy: „Do sali wszedł niski człowiek w obszernym płaszczu. Potykał się o krzesła, omal nie przewrócił stojaka z kwiatami. - Pijany? - mruknął Chmieleński? - Nie, znowu nie założył okularów, prawie ślepy" (PWW, 402). W dalszej części tej sceny okazuje się, że Bobrowski ma przy sobie pistolet, niedbale zatknięty za pasek: „Mój Boże, toż to chodzący arsenał i szaleniec!” - pomyślał Chmieleński, czując jednak rosnącą sympatię do oryginała" (PWW, 402). W posłowiu autorzy powołują się na pamiętniki przyjaciela Bobrowskiego i cytują z nich taki passus: „Przed wybuchem powstania i później wiecznie miał po kieszeniach pełno pistoletów, rewolwerów i sztyletów, które zbierał dla powstańców i nieraz czyniliśmy mu uwagę, że na ulicy wysuwała mu się na widok lufa albo ostrze" (PWW, 491). Jest to obraz - zarówno samego Bobrowskiego, jak i spiskowców - mocno odheroizowany, daleki od dykcji martyrologiczno-rewizjonistycznej dominującej w ciągu ostatnich stu pięćdziesięciu lat w literaturze pięknej poświęconej powstaniu ${ }^{33}$. Raz jeszcze powraca tu pytanie o tryb lektury wpisany w tekst powieści kryminalnej dwojga autorów: do jakiego stopnia zakłada on znajomość podstawowych faktów związanych z dziejami powstania 1863 roku? W posłowiu - spełniającym bez wątpienia, w zamierzeniu pisarzy, funkcję faktograficznego appendixu do tekstu powieściowego - nie znajdziemy na przykład informacji o tym, iż ten ekscentryczny młodzieniec dysponował nadzwyczajnym talentem organizacyjnym i niespożytą energią, które pozwoliły mu zapanować nad chaosem pierwszych tygodni insurekcji i usprawnić działania organizacji miejskiej, rzeczywiście w pewnych aspektach kontrolującej Warszawę (Bobrowski zginął 12 kwietnia 1863 roku, a dyktatura Langiewicza zakończyła się 19 marca). Oczywiście postać naczelnika stolicy jest dla powieściowej fabuły absolutnie marginalna i stanowi element owego „tła”, o którego wiarygodność historyczną

32 Warto dodać, że autorzy w posłowiu piszą o okolicznościach śmierci Bobrowskiego w następujący sposób: „Czy prawdą jest, że biali usiłowali fizycznie wyeliminować swych przeciwników politycznych i uknuli w tym celu spisek? Historia milczy na ten temat, lecz przecież to właśnie Stefan Bobrowski został wplątany w pojedynek i zastrzelony z zimną krwią przez awanturnika jednoznacznie powiązanego z obozem białych" (PWW, 491).

33 Nie sposób omówić tu nawet w zarysie tego kontekstu. Tym bardziej, że Paulina Małochleb w swojej książce Przepisywanie historii. Powstanie styczniowe w powieści polskiej w perspektywie kulturowej (Wydawnictwo Naukowe Uniwersytetu Mikołaja Kopernika, Warszawa-Toruń 2014) bardzo obszernie zanalizowała teksty literackie dotyczące wydarzeń 1863 roku. 
autorzy tak - w swoich deklaracjach - zabiegają. Niemniej ten epizod powieściowy zdaje się rzucać światło na tryb, w jakim przywoływane są fakty historyczne, czy w tym przypadku ewokowane „ciągi dalsze” przedstawianych zdarzeń i - w efekcie - w jakim owo tło jest konstruowane. Pojawia się tu przede wszystkim obraz przeszłości efektowny fabularnie (sztyletnicy, półślepy konspirator z pistoletem za paskiem), zatem dominanta powieści kryminalnej - z wyraźną domieszką elementów sensacyjnych - przeważa nad elementami powieści historycznej ${ }^{34}$.

Wyrażona expressis verbis w cytowanym posłowiu dbałość o zgodność realiów powieściowych z historycznymi ma ścisły związek z zastosowanym przez autorów chwytem mającym tę relację uwiarygodnić: zamieszczeniem w tekście zdjęć. To przede wszystkim fotografie dziewiętnastowiecznej Warszawy. Gdy zatem bohaterowie zostają zaproszeni na audiencję u oberpolicmajstra do ratusza, czytelnik może obejrzeć zdjęcie budynku wraz z objaśnieniem, co się w nim znajdowało. Kiedy akcja przenosi się na Pragę, na powieściowej stronie oglądamy fotografię targu końskiego, który tam funkcjonował. Taki zabieg zarówno eksponuje fundamentalnie mimetyczną relację kryminału z rzeczywistością zewnętrzną ${ }^{35}$, jak i podkreśla aspekt wierności realiom historycznym. Podobny efekt daje zamieszczenie przez autorów: kolejnych kartek z kalendarza odmierzających powieściowy upływ czasu (od 31.08. do 2.11.1862 roku); zdjęć postaci historycznych występujących w powieści (Kronenberga, Deotymy, Chmieleńskiego, samego Whichera ${ }^{36}$ ); szkiców dwóch rodzajów broni, która pojawi się w powieściowej fabule (rewolweru marki Lefaucheux i pistoletu typu pepperbox); wreszcie załączenie wizerunku statku parowego „Scotia” ${ }^{37}$, przewożącego list z protokołem policyjnym ze Stanów Zjednoczonych - pismem, na które Whicher czeka niecierpliwie, by móc zweryfikować informacje o ucieczce za ocean panny Dołgorukiej. Wszystkie te zabiegi

34 W każdym razie w takim kształcie tej konwencji, którą zawdzięczamy na przykład Władysławowi L. Terleckiemu, wyraźnie z kolei nawiązującemu do modelu dokumentarnej powieści historycznej skonstruowanego przez J.I. Kraszewskiego. Zob. A. Izdebska, Forma, ciało i brzemię imperium. O prozie Władysława L. Terleckiego, Wydawnictwo Uniwersytetu Łódzkiego, Łódź 2010, s. 85-87. Autorzy wyraźnie są tu bliżsi modelowi sienkiewiczowskiemu.

Zob. M. Czubaj, Etnolog w Mieście Grzechu. Powieść kryminalna jako świadectwo antropologiczne, Oficynka, Gdańsk 2010, s. 16.

36 Przy tej okazji dokonują odkrycia: „Ot, chociażby zdjęcie opublikowane na kilku witrynach jako portret Jonathana Whichera okazało się... podobizną Samuela Kenta, jednego z członków rodziny mieszkającej w rezydencji Road Hill” (PWW, 492).

37 Nadto w powieści czytamy: „SScotia» to nowy, dobry statek, do tego szybki: podobno rozwija prędkość ponad czternastu węzłów. Widziałem, jak wyruszał w swój dziewiczy rejs. Było to jakoś pod koniec maja tego roku [...]. Wybór padł na Queenstown, małe irlandzkie miasteczko nieopodal Cork. Wypłynięcie transatlantyku to nie lada wydarzenie w życiu sennej mieściny" (PWW, 217-218). Informacje te nie wnoszą niczego istotnego do fabuły powieściowej - budują jednak „efekt realności”, tak ważny wedle deklarowanych intencji autorów. 
wzmacniają referencję tekstu, najwyraźniej odsyłającego nas do rzeczywistości historycznej. Oczywiście autorzy odwołują się do podstawowych cech fotografii jako medium fundamentalnie indeksalnego, dającego świadectwo „widzialnemu światu" ${ }^{38}$.

Warszawę w kryminale Chodkowskiej-Gyurics i Bochińskiego oglądamy przede wszystkim oczami przybysza z zewnątrz - Whichera. Już w drodze z dworca Anglik zauważa dziwną monochromatyczność miejsca, w którym się znalazł:

Ulica wyglądała jak ożywiony dagerotyp. Mimo pięknego, słonecznego dnia miasto sprawiało ponure wrażenie. Wszędzie dominowały ciemne barwy: obszerne krynoliny dam, modne narzutki, kapelusze, szale, ba!, nawet ubrania dzieci uszyto głównie z czarnych i szarych materiałów. „Dziwny kraj, dziwni ludzie” - pomyślałem. „Ciekawe, czy taka tutaj moda, czy raczej jakiś kuriozalny zwyczaj albo smętne święto" (PWW, 17) ${ }^{39}$.

Ciekawość londyńskiego detektywa nie zostanie zaspokojona - jego przewodnikami po warszawskim świecie będą rosyjscy urzędnicy, głównie policjanci. Autorzy powieści posługują się tym funkcjonalnym zabiegiem narracyjnym z oczywistych powodów: daje im to możliwość wprowadzenia opisów rzeczywistości przedstawionej w sposób fabularnie je uwiarygodniający. Od czasów Jonathana Swifta prezentacja świata oczami obcego umożliwia pokazanie jej niejako „od podstaw”.

Zatem - na przykład - gdy Anglik wygląda przez hotelowe okno, zauważa:

Po drugiej stronie stała grupa zawzięcie o czymś dyskutujących Żydów. Wymachiwali rękami, krzyczeli, kiwali głowami. Dopiero teraz uświadomiłem sobie, jak wielu ich krąży po ulicach Warszawy. Przypominali wróble - głośne i wszechobecne. Ciekawe, o czym rozmawiali? Ubijali interes? Roztrząsali najnowsze skandale i skandaliki? A może tylko narzekali na pogodę? „A co mnie to, u diabła, obchodzi?" - pomyślałem, energicznie zatrzaskując okno (PWW, 254).

38 Pozostając w zgodzie z regułami gatunku, autorzy nie prowadzą tu żadnych wyrafinowanych gier w obrębie relacji tekst werbalny - znaki ikoniczne (fotografie). Jak pisała Anna Łebkowska o tak użytych w tekście literackim zdjęciach, są one ready made, „niosą w sobie znak dokumentu, służą zarazem złudzie bezpośredniego obcowania z rzeczywistością", Fotografia jako empatyczna mediacja, w: Intersemiotyczność. Literatura wobec innych sztuk (i odwrotnie), red. S. Balbus, A. Hejmej i J. Niedźwiedź, Universitas, Kraków 2004, s. 117. Innymi słowy fotografiom przypisuje się tu "moc świadczenia i referencji” (M. Koszowy, W poszukiwaniu rzeczywistości. Mediacyjna rola fotografii we współczesnej prozie polskiej, Universitas, Kraków 2013, s. 34).

39 Fraza na temat „dziwnego kraju” pochodzi z powieści Marii Rodziewiczówny Między ustami a brzegiem pucharu (zob. na przykład wydanie: Ludowa Spółdzielnia Wydawnicza, Warszawa 1974, s. 64). Funkcja tego intertekstualnego zabiegu nie wydaje się w kontekście całości tekstu jasna - zapewne jest to po prostu erudycyjny żart autorów. 
W innej scenie, gdy detektyw zjawia się na świeżo oddanym do użytku Dworcu Petersburskim, opisuje kontrast między nim a Dworcem Wiedeńskim, pełnym ruchu, gwaru ludzi, gwizdu lokomotyw i stukotu kół. O nowym budynku mówi: „był martwy [...] wciąż jeszcze pachniał niezaschnięta farbą i świeżym drewnem” (PWW, 173). Dociekliwy czytelnik - obejrzawszy załączone zdjęcie budynku - może sięgnąć po źródła ${ }^{40}$ i poczytać o historii dworca oddanego do użytku rzeczywiście w 1862 roku i spalonego przez wycofujące się wojska rosyjskie w 1915 oraz zlokalizować nieistniejący już Dworzec Wiedeński. Powieściowy dialog zaś dostarczy mu wiedzy o rozstawie szyn w Imperium Rosyjskim - niezorientowany Whicher snuje bowiem wizję połączenia linii kolejowych rosyjskiej i austriackiej. Ten aspekt poznawczy kryminału historycznego - jeśli uwzględnić pewien typ wnikliwej lektury - bywa niedoceniany.

Ostatecznie jednak Whicher postrzega Warszawę jako miasto, które jest w pewnych aspektach podobne do innych. W czasie spaceru po ulicach trafia na starówkę i jego rynek: „otoczony ze wszystkich stron wysokimi, kolorowymi kamieniczkami. Brukowany plac gęsto zastawiono nędznymi straganami. [...] Nad całością górował zupełnie niepasujący do otoczenia, ustawiony na cokole w kształcie skały ${ }^{41}$, błyszczący posąg kobiety z rybim ogonem" (PWW, 234-235). Angielski detektyw obserwuje ruch na ulicy i zostaje okradziony przez małego ulicznika, jednak natychmiast odzyskuje portfel: „znam ci ja takich łobuziaków jak zły szeląg. Złapałem huncwota za kołnierz i gestem pokazałem, co ma zrobić" (PWW, 235). Komentuje swoją przygodę następująco: „Cóż, pewne rzeczy wszędzie są takie same: czy to Londyn, Warszawa, Paryż czy Kair" (PWW, 235). Autorzy Pana Whichera $w$ Warszawie nie usiłują wpisać przestrzeni miasta w semantykę uruchamianą przez polską powieść dziewiętnastowieczną. Stare Miasto w tym czasie, szczególnie w tekstach Józefa Ignacego Kraszewskiego, jest enklawą polskości, miejscem patriotycznych demonstracji, przestrzenią szczególnie nasyconą pamięcią przeszłości ${ }^{42}$.

Warszawa nie jest tu zatem miejscem jakkolwiek szczególnym, nacechowanym, jest „wiecznym miastem na ruchomych piaskach”43. Mimo dziwności jego

40 Na przykład Encyklopedia Warszawy, red. B. Kaczorowski, Wydawnictwo Naukowe PWN, Warszawa 1994, s. 160; lub J. Kasprzycki, Korzenie miasta. Warszawskie pożegnania, t. 3: Praga, Wydawnictwo Veda, 1998, s. 184.

41 Autorzy popełniają tu błąd rzeczowy - w 1862 roku posąg stał na prostym, geometrycznym cokole - stylizowana skała jako podstawa pomnika pojawiła się dopiero na początku XX wieku. Zob. Katalog zabytków sztuki. Miasto Warszawa, cz. 1: Stare Miasto, oprac. Jerzy Łoziński, Andrzej Rottermund, Wydawnictwo Artystyczne i Filmowe, Warszawa 1993, s. 410; oraz W. Głębocki, Warszawskie pomniki, PTTK „Kraj”, Warszawa 1990, s. 52.

42 Zob. na przykład E. Paczoska, "Lalka” czyli rozpad świata, Trans Humana Wydawnictwo Uniwersyteckie, Białystok 1995, s. 13-14.

43 Zob. M. Zielińska, Warszawa - dziwne miasto, Wydawnictwo Instytutu Badań Literackich PAN, Warszawa 1995. 
mieszkańców, to typowa przestrzeń miejska, w której toczy się intryga kryminalna: $z$ centrum (Plac Teatralny, Krakowskie Przedmieście) oraz malowniczą dzielnicą nędznych zaułków - Pragą - w której obrębie ważną rolę spełnia browarnia „U Kazka”.

Ostatecznie o przynależności gatunkowej powieści Pan Whicher w Warszawie decyduje jej referencja - tekst odsyła do przeszłości historycznej udokumentowanej również w historiografii. Jednak to, co stanowi o specyfice Pana Whichera $w$ Warszawie, ale i o pewnej zmianie tonu, która nastąpiła w polskiej literaturze - w tym przypadku popularnej - jest punkt widzenia, $\mathrm{z}$ jakiego prowadzona jest narracja. Powieściowe zdarzenia na tle rzeczywistości przedpowstaniowej oglądamy nie tylko oczami „obcych”: angielskiego detektywa i rosyjskiego policjanta prowadzącego śledztwo. Co więcej, w jednej z powieściowych scen rosyjski policjant, sprowokowany przez kolegę narzekającego na to, że Warszawa jest nudnym, prowincjonalnym miastem („Ledwie zobaczyłem $\mathrm{z}$ okien powozu, trzeba było zemknąć", PWW, 293), zaczyna snuć opowieść o okolicznościach, w jakich on sam po raz pierwszy oglądał Warszawę:

Z okien powozu, mówisz Fom’ Fomicz? Ja zaś z końskiej kulbaki. I wtedy to miasto wydało mi się ogromne i ciekawe. I tak jest do dziś - odrzekł zamyślony Wawiłon Aleksandrowicz. [...] Zresztą początkowo i ja byłem znudzony... Siedziałem wtedy od rana w siodle, tuż obok marszałka Dybicza, obserwując początkowo białe, a potem wydeptane błotniste pole przed sobą. Nuuuda [...]. Ale tylko mnie było nudno. Nasi chłopcy, grenadierzy i jegrzy, od bladego świtu próbowali dostać taki lasek, co nam drogę na Pragę i most zamykał. Wiele razy gęste kolumny szły tak hardo, że feldmarszałek nie miał wątpliwości - Olszyna będzie wzięta we kwadrans. Po czym nasze kolumny, przyjęte ogniem rotowym, stawały skłębione. Na to wysuwały się z lasku linie identycznie jak nasi umundurowanych żołnierzy, tyle że czaka mieli nieozdobione gałęźmi choiny, i następowało uderzenie na bagnety (PWW, 293-294).

Czytelnik otrzymuje zatem relację rosyjskiego uczestnika bitwy o Olszynkę Grochowską z 1831 roku, relację, jak twierdzi jeden ze słuchaczy, podkoloryzowaną. Nie wierzy, że polska piechota dopuszczała szarżujących kirasjerów na piętnaście kroków i dopiero wtedy oddawała salwę. Jednak do rozmowy włącza się inny policjant:

Prawdę mówi radca - rzekł cicho Kazimierski, siorbiąc herbatę. - Byłem tam. - Wy? Gdzie? Chyba w łonie matki! - uśmiał się Foma Fomicz. - Byłem synem 8. pułku, nosiłem bęben i stałem w czworoboku, na który szarżował Wawiłon Rożestwieński. Dowodził Karol Karski, stary napoleończyk. Dotąd mam w domu kask kirasjerski i zielony kołnierz odpruty z munduru (PWW, 295). 
Mamy tu więc opowieść dwóch weteranów o epizodzie z wojny, w której walczyli po przeciwnych stronach, a teraz ramię w ramię pracują dla zwycięzców i wspominają przy herbacie kombatancką przeszłość. Ta przeszłość zdaje się jedynie dla nich obu mieć emocjonalną temperaturę wspomnień z młodości. To, co w tym usytuowaniu narracyjnym uderza - i co jest charakterystyczne dla całej powieści, nie tylko dla przywołanej powyżej sceny - to nie wprowadzenie rosyjskiego punktu widzenia w opowieść o zdarzeniach z roku 1831 i 1862. Takie zabiegi w literaturze polskiej opowiadającej o rzeczywistości porozbiorowej wykorzystywane były dość często. Jednak w powieści Chodkowskiej-Gyurics i Bochińskiego ciekawe jest to, że nie tylko spojrzenie najeźdźcy, bądź co bądź, jest waloryzowane, ale i często czytelnik z punktem widzenia rosyjskiego bohatera się utożsamia. Kibicujemy Czernyszewskiemu w śledztwie, współczujemy pobicia przez krewkich polskich spiskowców, obawiamy się o jego życie, gdy zostaje przez nich porwany, jesteśmy źli, gdy polscy sztyletnicy zamierzają „zdjąć” Whichera - jednego z dwóch głównych bohaterów powieści. Tym samym ma się wrażenie, że dziewiętnastowieczna rzeczywistość została odczarowana, pozbawiona emocjonalnego, traumatycznego wymiaru, wyjęta $\mathrm{z}$ ram romantycznego paradygmatu. Jednak opowieść o przygodach angielskiego detektywa w Warszawie wpisana została $\mathrm{w}$ dwie sceny ramowe narad $\mathrm{w}$ gronie najwyższych urzędników carskich nad Wisłą. Pierwsza z nich toczy się 31.08.1862, druga 2.11. tego samego roku - obie dotyczą napiętej sytuacji w byłej polskiej stolicy. W akapicie otwierającym powieść czytamy: „bal dobiegał końca [...]. Orkiestra jednak niestrudzenie trwała na stanowisku, najnowsze wiedeńskie i paryskie melodie wypełniały pilnie strzeżony gmach i wylewały się na ulice niepokornego miasta" (PWW, 5). Zamyka zaś tekst następujący fragment, rozpoczynający się od wypowiedzi wielkiego księcia Konstantego:

Da Bóg, zdławimy buntowników w parę tygodni, a potem... potem nikt w tym niewdzięcznym kraju już nie będzie śmiał nam stawić oporu. Muchanow chciał jeszcze coś powiedzieć, ale zmilczał, zapatrzył się tylko w ciemność za oknami. Tam miasto, ciche jak wulkan przed wybuchem, obchodziło stare święto, czcząc zmarłych. Czerpiąc otuchę i przykład z ich życia, gromadząc siły do kolejnej próby, albowiem Polacy mieli zupełnie inne zdanie w kwestii stawiania oporu niż namiestnik cara, wielki książę Konstanty Mikołajewicz Romanow (PWW, 486).

Zdania te brzmią odmiennie od innych tonów obecnych w powieści i zdają się świadczyć o niewygasłej jednak sile romantyczno-martyrologicznego rejestru w opowieściach o latach sześćdziesiątych dziewiętnastego wieku. A właściwie jego popularnej kliszy, bo przecież, jak słusznie zauważa Małgorzata Kosmala, $\mathrm{z}$ taką reprezentacją przeszłości historycznej mamy do czynienia w tego typu 
literaturze $e^{44}$. A może - mimo niezobowiązującej formuły kryminału historycznego - autorom udało się uchwycić schizofreniczne rozdarcie wpisane w nasz ogląd tamtej rzeczywistość? Odległej czasowo, ale powracającej wciąż emocjonalną czkawką?

Drugą z wymienionych na początku tego tekstu powieści, Carską roszadę autorstwa Melchiora Medarda, przywołuję tu, ponieważ jest ona skonstruowana wedle pozornie tego samego, co Pan Whicher $w$ Warszawie wzorca. Jednak podobieństwo jest złudne. Nie zamierzam zresztą analizować dzieła Medarda obszernie - powieść interesuje mnie raczej jako przykład gry z konwencją kryminału historycznego i jako kolejna opowieść, której zdarzenia - rozgrywające się w wieku XIX na polskich ziemiach - oglądamy oczami rosyjskiego bohatera.

Akcja Carskiej roszady toczy się w 1890 roku, także w Warszawie, i dotyczy śledztwa w sprawie morderstw, których sprawcy (jak się okaże jest ich kilku) najwyraźniej są brutalnymi psychopatami. Pozornie mamy tu do czynienia z podobną formułą gatunkową - kryminałem historycznym - jednak autor prowadzi tak ostentacyjną grę z czytelniczą znajomością rozmaitych kontekstów czy intertekstów, że kwestią problematyczną staje się referencja powieści. Ponieważ nie sposób wyliczyć tu wszystkich zabiegów tego rodzaju, poprzestanę na kilku, dla zilustrowania tezy, że na pytanie, do jakiej rzeczywistości odsyła nas Medard, nie ma jednoznacznej odpowiedzi. Przede wszystkim sama postać prowadzącego śledztwo Estara Pawłowicza Van Houtena jest wyraźnie wzorowana na Eraście Fandorinie, bohaterze serii kryminałów Borysa Akunina, a i tytuł powieści jest dość klarowną aluzją do Tureckiego gambitu, drugiej w cyklu opowieści o rosyjskim detektywie. Zatem nie złożone gry z punktem widzenia „obcego”, a raczej związek z intertekstem (czy raczej zbiorem intertekstów) decyduje o tym, iż wydarzenia w powieści obserwujemy z perspektywy Rosjanina. Akuninowska wersja schyłku dziewiętnastego stulecia zdaje się bezustannie z tła tekstu Medarda przebijać. Nadto autor raczy nas rozmaitymi erudycyjnymi żartami: zarządca kancelarii generała-gubernatora to Akakij Jegorycz Baszmaczkin (Gogolowski bohater Płaszcza ma tylko inne otcziestwo: Akakijewicz), jeden z morderców nazywa się Max Frisch, drugi Friedrich - dwojga imion - Caspar Wilhelm (znany nam Friedrich to oczywiście Caspar David). Ponadto: Van Houten odwiedza sklep Wokulskiego na Krakowskim Przedmieściu; raport, który Estar Pawłowicz pisze dla swoich przełożonych, brzmi: „Dzień pierwszy. Na Zachodzie bez zmian” (SR, 65)"45; fragment powieściowego dialogu wygląda następująco: „Tak. Skończmy z tym jeszcze dzisiaj. Nie

44 M. Kosmala, Kryminalne retroświaty, w: Przerabianie XIX wieku, red. E. Paczoska i B. Szleszyński, Państwowy Instytut Wydawniczy, Warszawa 2011, s. 245.

45 Wszystkie cytaty w tekście za wydaniem: M. Medard, Carska roszada, Instytut Wydawniczy Erica, Warszawa 2012, oznaczone są skrótem CR. 
będzie Niemiec pluł nam w twarz..." ${ }^{\text {"6 }}$ (CR, 305); gdy zaś mowa o prowokacji przygotowanej przez wywiad niemiecki, określa się ją jako: „Tak skomplikowaną, kosztowną i długotrwałą, jak turecki gambit...” (CR, 298). Te zabawy stanowią bonus dla erudycyjnego czytelnika, ale są też sygnałem, że rzeczywistość konstruowana w Carskiej roszadzie odsyła nas przede wszystkim - jeśli nie wyłącznie - do realiów innych tekstów literackich. Efekt ten wzmocniony jest informacjami zamieszczonymi w aneksie, w którym autor wyznaje, że, pisząc powieść, korzystał ze zbiorów International Detective Archives, gdzie zdeponowano Acta Fandoriana, memuary Miss Marple, Tekę wspomnień H. Poirot czy Zapiski na mankietach dra Watsona.

Mimo to tekst powieści poprzedzają trzy fotografie: placu Staszica, Krakowskiego Przedmieścia i placu Teatralnego - wszystkie datowane na rok 1890. Na wewnętrznej stronie okładki umieszczono zaś plan miasta $\mathrm{z}$ tego czasu. Zabiegi te zdają się z kolei sugerować, że opowieść o Van Houtenie odsyła nas do rzeczywistości historycznej, przestrzeni dokumentowanej niejako na tych fotografiach i ujętej w porządek mapy.

Konfuzji czytelnika dopełniają też takie fragmenty, które w opowieść o poszukiwaniu psychopatycznego seryjnego mordercy - radca został przysłany do Warszawy, bo rozwiązał zagadkę tożsamości Kuby Rozpruwacza ${ }^{47}$ - wprowadzają niespodziewanie inny ton. A jest to historia, należy tu dopowiedzieć, pełna sensacyjnych zwrotów akcji, drastycznych szczegółów zbrodni, pościgów, relacji z nocnego życia Warszawy i opisów ostrego lesbijskiego seksu. Ale kiedy Estar Pawłowicz spaceruje w wigilię Bożego Narodzenia po mieście, doświadcza takiego oto przeżycia:

W końcu runął, podobny gromom, wielkim chórem setek gardeł w wąskie przesmyki zaułków i popłynął ku Wiśle: „Bóg się rodzi, moc truchleje...” Radca aż się oparł o ścianę - nigdy w życiu nie słyszał czegoś tak potężnego, tak pięknego i tak wspólnego... To śpiewali biedacy na poddaszach, w suterenach i bogacze na piętrach. Grubi i chudzi, zdrowi i gruźlicy - wszyscy razem. Otwarły się okna i hymn popłyną jak orkan, wirując w krętych uliczkach na rynek ${ }^{48}$, a stamtąd ku katedrze i odbijając się o jej czerwone, mocarne ściany, uniósł się ku niebu. Radca ani drgnął, słuchał. I zrozumiał. Żaden pejcz, szubienica ani kibitki nie pokonają tego miasta.

46 Warto może przypomnieć, że Konopnicka napisała Rotę w 1908, akcja powieści, przypominam, to rok 1890.

47 Jak wiadomo w rzeczywistości zagadka tożsamości najgłośniejszego mordercy w wiktoriańskiej Anglii nie została rozwiązana.

48 Rosyjski radca przeżywa zatem porażenie chórem polskich głosów - co ma posmak dodatkowy - na Starym Rynku. Zob. przypis 42. 
Tego narodu. Albo Rosja z nim się sprzymierzy, albo będzie wrogiem. Nie ma innego wyjścia. Śmierć albo życie ${ }^{49}$ (CR, 165-166).

Scena ta uderza patosem i niespecjalnie respektuje reguły prawdopodobieństwa, choćby dlatego, że owego porażenia chórem głosów polskich doświadcza człowiek wychowany w prawosławiu, który zapewne śpiewów cerkiewnych słuchał nie raz, zaś otwieranie okien w grudniowe mrozy raczej nie było zwyczajem powszechnym w dziewiętnastowiecznej Warszawie.

Ów mariaż dykcji i porządków powoduje, że kwalifikacja genologiczna Carskiej roszady pozostaje kwestią niejednoznaczną. Taka eklektyczność zresztą, jak się wydaje, jest zgodna $\mathrm{z}$ autorskimi intencjami - powieść ma bowiem nieco żartobliwy podtytuł: „Opowieść prawie sensacyjna, momentami romansowa, częściej zagadkowa, niekiedy erotyczna”. W tym wyliczeniu brak przymiotnika „historyczna”, czy „kryminalna”. Co oczywiście nie zwalnia z poszukiwania dominanty gatunkowej tej powieści ${ }^{50}$. Jakkolwiek jednak by jej nie określać, formuła kryminału

49 Retoryka „my albo oni”, która się pojawia w tym fragmencie, mocno przypomina najczęściej chyba cytowany passus z Zapisków o powstaniu polskiem 1863 i 1864 roku i poprzedzajacej powstanie epoce demonstracyi od 1856 Mikołaja Berga, w polskim wydaniu zamieszczonych w epilogu, dołączonym przez Berga w 1884 roku, po dwudziestu latach od pierwszego wydania. Brzmi on: „Polacy, czy to w Królestwie Polskim, na Litwie i Rusi, nie przestaną nigdy być Polakami takimi, jakich widziało ich już kilka rosyjskich pokoleń. Zawsze oni w głębi swych serc żywić będą te same nadzieje, te same marzenia i nie pozbędą się swej nienawiści do wszystkiego, co rosyjskie. [...] Pozbądźmy się marzeń. Na ogromnej przestrzeni, między Bałtykiem a Czarnym Morzem, między Uralem a zachodnią Europą dwóch panów być nie może. Rosja bądź Polska musi wyłącznie rządzić i gospodarzyć. My albo oni. Innego rozwiązania kwestii Polski nie ma i być nie może" (M. Berg, Zapiski o powstaniu polskiem 1863 i 1864 roku i poprzedzającej powstanie epoce demonstracyi od 1856, przeł. K.J., Kraków 1898, t. 3, s. 453-454).

50 Opinia jednej z czytelniczek, która na takie poszukiwania się udała, jest dość miażdżąca: „Opowieść prawie sensacyjna, momentami romansowa, częściej zagadkowa, niekiedy erotyczna” - widniejące na okładce słowa witają nas i próbują sugerować, że czeka nas niezwykle barwna, różnorodna gatunkowo powieść. Do tego opis na okładce - XIX-wieczna Warszawa, śledztwa, morderstwa kobiet. Wszystko wydaje się brzmieć intrygująco, a i czytelnik oczekuje porywającej historii, która będzie trzymać go do końca w napięciu. Jednak wraz z przewróceniem ostatniej strony, po zapoznaniu się z aneksem i wzięciu oddechu, zaczęłam odnosić wrażenie, że przytoczone hasło było tylko asekuracją ze strony wydawnictwa. Bo w ostatecznym rozrachunku, ni to kryminał, ni sensacja, ni romans, a tym bardziej literatura erotyczna. Czym w takim razie jest Carska Roszada, która wyszła spod pióra Melchiora Medarda? [...] Historia, kryminał, sensacja, erotyzm i romans. Wielu autorów próbuje swych sił tworząc hybrydy - przy czym wielu z nich polega. Bo łączenie gatunków nie jest sprawą prostą, wymaga dużej dyscypliny, ale i logicznego myślenia, ułożenia i przede wszystkim przemyślenia każdego wątku. Taka powieść ma nie być zupą «śmieciówką», a wykwintnym daniem, gdzie każdy składnik znalazł się na talerzu z jakiegoś powodu i tworzy z pozostałymi spójną kompozycję", zob. https://okona- 
historycznego wydaje się tu wątpliwa do zastosowania ze względu na podstawowe kłopoty z referencją, które już sygnalizowałam. Carska roszada odsyła bowiem raczej do porządku tekstów, nie do rzeczywistości historycznej roku 1890.

Obie przywołane tu powieści, bez względu na szczegółowe kwalifikacje genologiczne, należą do literatury zwanej popularną. Obie stanowią swoistą grę $\mathrm{z}$ rozmaicie konstruowanym w polskiej kulturze obrazem wieku XIX. Jeśli uznać za słuszną tezę Agnieszki Fulińskiej, iż literatura popularna jest popularna, bo - między innymi - stanowi zwierciadło czasów, w których jest tworzona ${ }^{51}$, to obie analizowane przeze mnie powieści można potraktować jako odzwierciedlenie naszego emocjonalnego stosunku do dziewiętnastowiecznej przeszłości. Pewna schizofreniczność obrazu tego wieku wpisana w oba teksty może być zatem pochodną tyleż rozmaitych komplikacji gatunkowo-konwencjonalnych, co - po prostu - świadectwem naszego współczesnego uwikłania w klisze romantycznego paradygmatu. Mają one najwyraźniej taką siłę emocjonalnego rażenia, że stanowią nieusuwalny składnik opowieści o wieku XIX nawet wtedy, gdy podstawowymi składnikami mieszanki są krwawa intryga kryminalna, niemal pornograficznie przedstawiona erotyka, czy sztyletnicy uciekający po warszawskich dachach, a całość bywa podlana rozmaitymi intertekstualnymi grami. W rezultacie, w obu utworach, obraz „wieku pary i elektryczności”, a także czasów, kiedy „poszli nasi w bój bez broni”, stanowi melanż nostalgii i retoryki traumy, który najwyraźniej rządzi polską zbiorową wyobraźnią drugiej dekady dwudziestego pierwszego wieku.

kulture.pl/2014/o4/o9/2188,zupa-smieciowka-carska-roszada-melchiora-medarda/ [dostęp: 27.07.2017]. Nawiasem mówiąc - uwagi tej czytelniczki świadczą o jej niechęci do mnogości konwencji narracyjnych i punktów widzenia zastosowanych przez Medarda. Dowodziłoby to prawdziwości konstatacji Bogdana Owczarka twierdzącego, że w literaturze dającej się zaklasyfikować jako popularna nie akcentuje się „dyskursywnego aspektu narracji” (Narratologia i narracyjność literatury popularnej, w: Nowe formy w literaturze popularnej, Wydział Polonistyki Uniwersytetu Warszawskiego, Warszawa 2007, s. 31). Nadmierne "utekstowienie” powieści w tej konwencji - jak się okazuje - zadziałało na niekorzyść autora Carskiej roszady. Przeciętni odbiorcy literatury tego typu nie są raczej wyczuleni na gry metatekstowe.

51 A. Fulińska, Dlaczego literatura popularna jest popularna?, „Teksty Drugie” 2003, nr 4, s. 61. Podobną tezę głosi na przykład Marek Krajewski, pisząc o współczesnych badaniach nad kulturą popularną odchodzących od wartościowania: „w ich obrębie jest ona traktowana jako kultura nie-obca, swojska, nasza, własna, najlepiej odzwierciedlająca nasze potrzeby, obowiązujące kulturowe kategorie ujmowania świata i reguły działania wobec niego. Kultura popularna jest tu więc medium, poprzez które wyrażane są codzienne doświadczenia, i formą, w jakiej codzienność jest praktykowana" (M. Krajewski, Kultury kultury popularnej, Wydawnictwo Naukowe Uniwersytetu Adama Mickiewicza, Poznań 2003, s. 30-31). 


\section{Bibliografia}

Bradshaw Smith Donna, Bruce Alexander: Sir Henry Fielding and Blind Justice, w: The Detective as Historian: History and Art in Historical Crime Fiction, ed. R.B. Browne and L.A. Kreiser Jr, Bowling Green State University Popular Press, Bowling Green 2000, s. 175-185.

Chodkowska-Gyurics Agnieszka, Bochiński Tomasz, Pan Whicher $w$ Warszawie, Instytut Wydawniczy Erica, Warszawa 2012.

Czubaj Mariusz, Etnolog w Mieście Grzechu. Powieść jako świadectwo antropologiczne, Oficynka, Gdańsk 2010.

Dominas Konrad, Antyk w kryminale, kryminat w antyku. Steven Saylor i recepcja literatury antycznej, w: Literatura kryminalna. Na tropie źródeł, pod red. Anny Gemry, Wydawnictwo EMG, Kraków 2015, s. 221-241.

Drozdowski Marian Marek, Zahorski Andrzej, Historia Warszawy, Wydawnictwo Jeden Świat, Warszawa 2004.

Eco Umberto, Lector in fabula. Współdziałanie w interpretacji tekstów narracyjnych, przeł. Piotr Salwa, Państwowy Instytut Wydawniczy, Warszawa 1994.

Eldridge David N., Westervelt Theron M., Meek Edward L., Michael Clynes: The Recollections of Shallot, w: The Detective as Historian: History and Art in Historical Crime Fiction, ed. R.B. Browne and L.A. Kreiser Jr, Bowling Green State University Popular Press, Bowling Green 2000, s. 156-168.

Encyklopedia Warszawy, red. Bartłomiej Kaczorowski, Wydawnictwo Naukowe PWN, Warszawa 1994.

Fulińska Agnieszka, Dlaczego literatura popularna jest popularna?, „Teksty Drugie” 2003, nr 4, s. 55-66.

Głębocki Wiesław, Warszawskie pomniki, PTTK „Kraj”, Warszawa 1990.

Izdebska Agnieszka, Forma, ciało i brzemię imperium. O prozie historycznej Władysława L. Terleckiego, Wydawnictwo Uniwersytetu Łódzkiego, Łódź 2010.

Izdebska Agnieszka, Kryminat historyczny, „Zagadnienia Rodzajów Literackich” 2016, t. 59, z. 4 (120), s. 137-143.

Kaczyński Paweł, Kryminał historyczny - próba poetyki, w: Literatura kryminalna. Śledztwo w sprawie gatunków, pod red. Anny Gemry, Wydawnictwo EMG, Kraków 2014, s. 191-209.

Kasprzycki Jerzy, Korzenie miasta. Warszawskie pożegnania, t. 3: Praga, Wydawnictwo Veda, Warszawa 1998.

Katalog zabytków sztuki. Miasto Warszawa, cz. 1: Stare Miasto, oprac. Jerzy Łoziński, Andrzej Rottermund, Wydawnictwo Artystyczne i Filmowe, Warszawa 1993.

Kosmala Małgorzata, Kryminalne retroświaty, w: Przerabianie XIX wieku. Studia, pod red. Ewy Paczoskiej i Bartłomieja Szleszyńskiego, Państwowy Instytut Wydawniczy, Warszawa 2011, s. 223-245. 
Koszowy Marta, W poszukiwaniu rzeczywistości. Mediacyjna rola fotografii we współczesnej prozie polskiej, Universitas, Kraków 2013.

Krajewski Marek, Kultury kultury popularnej, Wydawnictwo Naukowe Uniwersytetu Adama Mickiewicza, Poznań 2003.

Lemann Natalia, Polski steampunk - zaadaptować historię, adaptując konwencję, „Postscriptum Polonistyczne" 2015, nr 5: Adaptacje II. Transfery kulturowe, s. 133-147.

Lemann Natalia, Steampunk, „Zagadnienia Rodzajów Literackich” 2014, t. 17, z. 1 (113), s. 344-349.

Lowenthal David, Przeszłość to obcy kraj, przekł. Irena Grudzińska-Gross i Maciej Tański, „Res Publica” 1991, nr 3, s. 6-22.

Łebkowska Anna, Fotografia jako empatyczna mediacja, w: Intersemiotyczność. Literatura wobec innych sztuk (i odwrotnie), red. Stanisław Balbus, Andrzej Hejmej i Jakub Niedźwiedź, Universitas, Kraków 2004, s. 115-127.

Małochleb Paulina, Przepisywanie historii. Powstanie styczniowe w powieści polskiej $w$ perspektywie pamięci kulturowej, Wydawnictwo Naukowe Uniwersytetu Mikołaja Kopernika, Warszawa-Toruń 2014.

Małochleb Paulina, Sztyletnicy powstania styczniowego - historiografia i literatura. Rekonesans, „Teksty Drugie” 2008, nr 3, s. 184-193.

Medard Melchior, Carska roszada, Instytut Wydawniczy Erica, Warszawa 2012.

Owczarek Bogdan, Narratologia i narracyjność literatury popularnej, w: Nowe formy w literaturze popularnej, red. Bogdan Owczarek, Joanna Frużyńska, Wydział Polonistyki Uniwersytetu Warszawskiego, Warszawa 2007, s. 22-33.

Paczoska Ewa, „Lalka” czyli rozpad świata, Wydawnictwo Uniwersyteckie Trans Humana, Białystok 1995.

Paczoska Ewa, Wiek XIX - reaktywacja, w: Ewa Paczoska, Prawdziwy koniec XIX wieku. Śladami nowoczesności, Państwowy Instytut Wydawniczy Warszawa 2010, s. 244-262.

Piechota Dariusz, Reaktywacje dziewiętnastowieczności w najnowszej literaturze popularnej, „Tematy i Konteksty” 2015, nr 5 (10), s. 175-184.

Salamone Frank A., Maan Meyers: The Saga of Dutchman, w: The Detective as Historian: History and Art in Historical Crime Fiction, ed. Ray B. Browne and Laurence A. Kreiser Jr, Bowling Green State University Popular Press, Bowling Green 2000, s. 169-174.

Scaggs John, Crime Fiction, Routladge London \& New York, 2005.

Sulmicki Maciej, A Plenitude of Prefixes: Delineating the Boundaries of Neo-, Retro-, Faux-, Post-Victorian Literature, „Zagadnienia Rodzajów Literackich” 2015, t. 18, z. 1 (115), s. 9-26.

Summerscale Kate, Podejrzenia pana Whichera: morderstwo $w$ domu na Road Hill, przekł. Maria Jaszczurowska, Wydawnictwo W.A.B., Warszawa 2010.

The Detective as Historian: History and Art in Historical Crime Fiction, ed. R.B. Browne i L.A. Kreiser, Jr, Bowling Green 2000; t. 2, Newcastle 2007. 
Winks Robin W., Preface, w: The Detective as Historian: History and Art in Historical Crime Fiction, ed. R.B. Browne and L.A. Kreiser Jr, Bowling Green State University Popular Press, Bowling Green 2000, s. ix-x.

Worthington Heather, Key Concepts in Crime Fiction, Palgrave MacMillan, London 2011.

Zielińska Marta, Warszawa - dziwne miasto, Wydawnictwo Instytutu Badań Literackich PAN, Warszawa 1995.

\section{Pan Whicher w przedpowstaniowej Warszawie i radca Estar Van Houten w sklepie Wokulskiego - kryminał historyczny jako opowieść o przeszłości}

Streszczenie

Artykuł dotyczy dwóch powieści, które - pozornie lub rzeczywiście - są realizacją konwencji kryminału historycznego. Pierwsza z nich to Pan Whicher $w$ Warszawie Agnieszki Chodkowskiej-Gyurics i Tomasza Bochińskiego, druga to Carska roszada Melchiora Medarda. W tekście rozważane są aspekty genologiczne obu dzieł i konsekwencje owego gatunkowego usytuowania dla sposobu, w jaki ukazywana jest w nich dziewiętnastowieczna przeszłość. Ostatecznie - mimo różnic - w obu powieściach w sposobie konstruowania wieku XIX widać silne uwikłanie w dyskurs o romantyczno-martyrologicznej proweniencji.

Słowa kluczowe: kryminał historyczny; powieść historyczna; literatura popularna; XIX wiek w literaturze 


\title{
Mr. Whicher in the pre-Uprising Warsaw and councilor Estar Van Houten in Wokulski's shop - historical crime fiction as a story about the past
}

\author{
Summary
}

This article addresses two novels that, seemingly or truly, realise the historical crime convention. One of the novels is Pan Whicher $w$ Warszawie ("Mr. Whicher in Warsaw") by Agnieszka Chodkowska-Gyurics and Tomasz Bochiński, and the other one is Carska roszada ("The Tsar Castling") by Melchior Medard. Genre aspects of both works are considered, and the consequences the conventional location carries for the way in which the $19^{\text {th }}$ century reality is constructed in both novels. Finally - despite the differences between them - in both crime novels, the Polish history of the $19^{\text {th }}$ century is shaped via many elements; one of them is strong reliance on the discourse of romantic martyr-related provenance.

Keywords: a historical crime fiction, historical fiction, popular literature, the $19^{\text {th }}$ century in literature

Agnieszka Izdebska - dr hab. prof. UŁ; kierownik Katedry Teorii Literatury Instytutu Kultury Współczesnej Uniwersytetu Łódzkiego. Zajmuje się teorią powieści, badaniami genderowymi i ewolucją konwencji gotyckiej. Interesuje się też kulturą popularną, szczególnie różnymi odmianami powieści kryminalnej. Autorka książek Forma, ciało i brzemię imperium. O prozie Władysława L. Terleckiego (Łódź 2010), Literatura prze-pisana. Od „Hamleta” do slashu (Łódź 2015; współautor: Danuta Szajnert). 